İş ve İnsan Dergisi | The Journal of Human and Work

Y1l | Year: Ekim | October 2017

Cilt-Say1 | Volume-Issue: 4 (2)

ss I pp: $73-86$

doi: $10.18394 /$ iid.292957

e-ISSN 2148-967X

http://dergipark.gov.tr/iid/

Derleme Makalesi

\title{
Kadın Yöneticiler: Görünmez Engellerin Gölgesinde Yükselme Çabası
}

\author{
Women Managers: Struggle to Rise in the Shade of Invisible Obstacles
}

Gülçin Akbaşa ${ }^{\mathrm{a}}$, Leman Korkmaz ${ }^{*}$ b

\section{MAKALE BİLGISI}

Anahtar Kelimeler:

Cam tavan, Cam uçurum

Önyargl, Cinsiyet, Cinsiyet eșitsizliği

Tarihler :

Geliș 20 Şubat 2017

Düzeltme geliş 07 Ağustos

2017

Kabul 21 Eylül 2017

\section{ÖZ}

Günümüzde kadınlara yönelik önyargıyla ilgili farkındalık artsa da, is hayatında, özellikle yüksek pozisyonlar söz konusuysa, önyargının gizil formları varlı̆gını devam ettirmektedir. Cam tavan, kadınların çalıștıkları kurumlarda yükselmek istediklerinde, karșılaștıkları engelleri ifade eden ve kadınların ulaşabilecekleri en yüksek noktayı temsil eden görünmez bir bariyerdir. Yapılan güncel çalıșmalar, cam tavanı așmayı bașarsalar bile kadınların ayrımcıllğın farklı bir formuyla karşılaştı̆̆ına işaret etmiştir: Kadınlar daha çok şirketin durumunun kötüye gittiği yani riskli durumlarda yöneticilik pozisyonuna getirilmektedir. Araștırmacılar ayrımcıllğın gizil/örtük bir formu olarak değerlendirdikleri bu durumu "cam uçurum" terimiyle ifade etmiştir. Bu yazıda, çam uçurum kavramı farklı bulgulardan örneklerle açılklanmış ve farklı kuramsal yaklaşımlara değinilerek ele alınmıştır. Önyargılarla ilgili farkındalığın hem önyargılarla mücadele etmede hem de kadınların ve dolayısıyla kurumların bașarısı adına oldukça önemli olması nedeniyle bu çalışmada temel olarak iş hayatında kadınlara yönelik, özellikle de örtük düzeydeki, önyargılarla ilgili farkındalı̆̆l artırmak hedeflenmiștir.

\section{A R T ICLE INFO}

\section{Keywords:}

Glass ceiling, Glass cliff Prejudice, Gender, Gender inequalit

\section{Article history:}

Received 20 February 2017

Received in revised form 07

August 2017

Accepted 21 September

2017

\begin{abstract}
A B S T R A C T
Although there has recently been greater awareness on prejudices towards women, subtle form of prejudice in working life continue to exist. Glass ceiling is as a subtle and transparent barrier implying the upper limit that women can reach when they aim to increase their positions in an organization. Current studies indicated that even though women manage to break the glass ceiling they face with another form of discrimination: they are appointed to leadership positions during periods of crisis. Researchers evaluated this situation as an implicit form of discrimination against women and use "glass cliff" as a term to define the situation. In the current review, by giving examples from different studies glass cliff has been introduced as a concept; besides, the topic has been discussed from different theoretical perspectives. This paper's main aim is to increase awareness on prejudices towards women in working life because awareness is important tool to fight against prejudices and for the success of women and companies.
\end{abstract}

\footnotetext{
${ }^{a}$ Dr., Orta Doğu Teknik Üniversitesi, Ankara, Türkiye. ORCID: 0000-0001-6932-2022

*,b İletisim kurulacak yazar, Öğr. Gör. Dr., Baskent Üniversitesi, Ankara, Türkiye. ORCID: 0000-0003-2755-7290
} 


\section{GİRIŞ}

Son yıllarda üzerinde pek çok çalışma yürütülen önyarg1 kavramı, araştırmacılar tarafindan farklı ifadelerle tanımlanmaya çalışılmıştır. Örneğin, Davidson (2003) önyargıyı bireysel farklılıklarını dikkate almadan kişileri, sadece grup üyelikleri üzerinden yargılamak, onlara eşit ve adaletli olmayan şekilde davranmak olarak tanımlamıştır. Brown (2010: 7) ise bazı olumlu gibi görünen değerlendirme ve davranışların dolaylı olumsuz etkisini dikkate alarak önyargıyı "Bir gruba yönelik doğrudan ya da dolaylı bazı olumsuzluklar ya da antipatiye işaret eden ve bu grubun üyelerine yönelen duygu, tutum ya da davranış" olarak tarif etmiştir. Brown'ın tanımında en dikkat çekici noktalardan biri "dolaylı" olumsuzluklara yaptığı vurgudur. Brown bir gruba yönelik olumlu gibi görünen bazı değerlendirmelerin, dolaylı olarak olumsuz sonuçları olabileceğine dikkat çekmiştir. Örneğin, kadınların narin ve korunmaya muhtaç olduklarına dair yapılan değerlendirmeyi düşünelim: $\mathrm{Bu}$ inanç olumlu gibi gözükse de uzun vadede, kadınların yetkin algılanmaması ve yönetici pozisyonlarına daha az tercih edilmesine neden olabileceği için önyargılı bir tutum olarak değerlendirilebilir.

Kadınlara yönelik önyargıların azaldığını gösteren araştırma bulguları ya da kadınların eğitim ve seçme-seçilme gibi hakları elde etmiş olması cinsiyete dayalı önyargının geçmişe kıyasla azaldığını düşündürebilir. Rapor edilen ya da görünürdeki önyargının azalması önemli bir gelişme olsa da, kız çocuklarının okula gönderilmesine yönelik kampanyalara halen ihtiyaç duyuluyor olması, kadın cinayetlerine ilişkin istatistikler ve kadınların yüksek statülü işlerde daha az temsil edilmesi, toplumda var olan bu eşitlik dilinin samimiyetinin sorgulanması gerektiğine işaret etmiştir. Bu bağlamda, önyargılar üzerine çalışma yürüten araştırmacılar, önyargıların açık bir şekilde ifade edilmesinin, pek çok durumda kabul görmediği günümüzde, önyargının anket ve mülakat gibi yöntemler yerine daha gizil, örtük ya da bir diğer ifadeyle dolaylı yöntemlerle değerlendirilmesinin önemli olduğunu belirtmiştir (örn., Dovidio, Kawakami \& Gaertner, 2002; Greenwald, Poehlman, Uhlmann \& Banaji, 2009).

$\mathrm{Bu}$ çalışmada da iş hayatında, özellikle yüksek pozisyonlar söz konusu olduğunda, devam eden cinsiyet eşitsizliğine değinilecek, kadınların yöneticilik pozisyonlarına gelmesinin önünde engel teşkil eden ve dolaylı ölçümlerle varlığı ortaya konan cam tavan ve cam uçurum kavramlarından bahsedilecektir. Devamında ise, kadınların iş hayatında yüksek pozisyonlara gelmelerinin önünde engel teşkil eden bu örtük ayrımcıllk türlerinin altında yatan nedenler, farklı kuramsal yaklaşımlara değinilerek, ele alınacaktır.

\section{2. İŞ HAYATINDA KADIN}

Her ne kadar kadınların iş gücüne katılım oranı tüm dünyada artış gösterse de iş dünyasının baskın olarak erkekler tarafindan yönetildiğini ve erkeklerin iş hayatında daha ayrıcalıklı olduğunu söylemek mümkündür (Ragins, Townsend \& Mattis, 1998). Hegewisch ve Hartmann'ın (2014) Amerika'daki Kadın Politikaları Araştırmaları Enstitüsü için hazırladığı rapor kadınların tam zamanlı işlerden aldıkları ücretin erkeklerin $\% 76,5$ 'i kadar olduğunu ortaya koymuştur. Ayrıca bu raporda, kadınların belirli işlerde, özellikle daha düşük gelir getiren işlerde, temsilinin daha yüksek olduğu gösterilmiştir. 1972-2012 yılları arasında okul öncesi öğretmenliği, diş hekimi asistanlığ 1 ve hemşirelik gibi işlerde, istihdamın neredeyse yüzde yüzünü, değişim göstermeksizin, kadınlar oluştururken; 2012 yılına geldiğimizde bile kadınların mühendislik, avukatlık gibi alanlarda temsili \%10-20 bandında kalmıştır. Rowe (1990) kadınların ve diğer azınlık grupların belirli, özellikle de daha düşük gelir getiren işlerde sınırlı kalmalarını "cam duvarlar" terimiyle ifade etmiş̧ir. Türkiye İstatistik Kurumu'ndan (TUIK, 2016) alınan pek çok veri de Türkiye'deki kadınların karşılaştıkları ayrımcıllğı, cam duvarları ve ücret eşitsizliğini açık bir şekilde ortaya koymaktadır. 2015 yllına ait veriler Türkiye'deki erkeklerin okuma-yazma oranının kadınlara göre 5 kat daha fazla olduğunu, erkeklerin istihdamının kadınların istihdamından iki kat daha fazla olduğunu ve kadınların tüm eğitim düzeylerinde erkeklere kıyasla daha düşük ücret aldığını ortaya koymuştur (TUIK, 2016).

Kadınların iş hayatında karşılaşıtıkları engeller, eğitim ve ücret eşitsizliği ya da cam duvarlarla sınırlı değildir. Eğitim alabilen ve iş hayatında yüksek pozisyonlara gelen kadınlar da cam tavan ve cam uçurum olarak adlandırılan ayrımcılığın farklı formlarıyla karşılaşmaktadır.

\subsection{Cam Tavan}

Kadınların çalıştıkları pozisyonlar detaylı bir şekilde incelendiğinde, kadınların erkeklere kıyasla daha alt pozisyonlarda çalıştı̆̆, yönetici pozisyonlarında çoğunlukla erkeklerin yer aldığı görülmektedir. Bu bulgular, kadınların iş hayatında, erkek çalışanlarla eşit eğitim ve deneyime sahip olmasına rağmen, erkek çalışanlar kadar yükselemediğine işaret etmektedir. Cam tavan, 
kadınların çalıştıkları kurum ve organizasyonlarda yükselmek istediklerinde karşılaştıkları, engelleyici, ayrımcı değerlendirme ve davranışları kapsayan ve kadınların ulaşabilecekleri en yüksek noktayı temsil eden görünmez bir bariyerdir (Hymowitz \& Schellhardt, 1986). Bu ayrımc1 engellerin "cam tavan" olarak tarif edilmesinin nedeni, hedeflerin veya yüksek pozisyonların görünür olmas1; ancak engellerin görünmez, yani gizil olmasıdır. Başka bir deyişle, birçok ülkede ve kurumda cinsiyet eşitliğine yönelik hükümler yer alırken, görünmez engeller iş hayatında kadınların yükselmelerini engellemektedir. Kurumlarda ve şirketlerde cam tavanın varlığı, kadınların çoğunlukla alt veya orta düzeydeki pozisyonlarda çalışmasına ve üst yönetici pozisyonlarına ulaşamamasına neden olmaktadır.

Kadınların üst düzey yönetici pozisyonlarında daha düşük oranda temsil edilmesi; kadınların daha az eğitimli olması, almış olduğu eğitimi ve potansiyeli yeterince iyi kullanamaması, daha az deneyimli olması ve liderlik vasıflarını taşımaması gibi çeşitli nedenlerle ilişkilendirilebilir. Ancak, yürütülen araştırmalarda, cam tavanın temelinde mentor ve rol modeli eksikliği, cinsiyet ayrımcılı̆̆ı, bilgi ağından dişlanma (Sabharwal, 2015), yükselme ihtimalinin olmadığı alanlarda çalışma (Örücü, Kılıç \& Kılıç, 2007) gibi ayrımcı süreçlerin yer aldığı ortaya konmaktadır. $\mathrm{Bu}$ bulgular kadınların erkeklere kıyasla liderlik için daha az yetkin olduğu savını çürütmektedir.

Tüm dünyadan ve Türkiye'den veriler cam tavanın varlığını doğrular niteliktedir. The Economist (2015) dergisinin cam tavanla ilişkili verileri incelendiğinde, dünyada hiçbir ülkenin cam tavanı henüz aşamadığı, cinsiyet eşitsizliğinin en az olduğu ülkelerde bile kadınların yüksek yönetici pozisyonlarında çalışma oranının \%32 olduğu görülmektedir. The Economist' in (2015) verilerine göre, Türkiye'de kadınların yüksek yönetici pozisyonlarında çalışma oranı \%10'dur ve Türkiye, iş hayatına katılımda kadın-erkek eşitsizliğinin en yüksek olduğu ülkeler arasındadır. The Economist'in (2015) verilerini destekler nitelikte, TUIKK (2015) verilerine göre, 2014 yılında kadınların üst yönetici pozisyonlarındaki temsili $\% 9,4$ iken, kadın hakimlerin temsili \%36,9 ve 20132014 öğretim yılı için kadın profesörlerin temsili \%28,7'dir. Ayrıca, bugün Türkiye Büyük Millet Meclisi'nde 469 erkek milletvekiline karşın, sadece 81 kadın milletvekili bulunmaktadır; kadınlar meclisteki toplam nüfusun sadece \%14.73'ünü oluşturmaktadır (Türkiye Büyük Millet Meclisi, 2016).

Cam tavanın varlığı kadınların iş hayatına katılımını ve iş hayatındaki varlığını olumsuz etkilerken, bu durumdan şirketler de olumsuz etkilenmektedir
(Morrison, White \& Van Velsor, 1987). Yetenekli ve başarılı olabilecek insanların sadece belirli bir kısmını kullanmak gelişme potansiyelinin de önüne geçebilmektedir (Grant Thornton International Business Report, GTIBR, 2015). Kurumların gelişimi, farklı ve çeşitli becerilere sahip olmakla iliş̧ilidir ve şirketlerde hem kadın hem de erkek yöneticilerle çalışmak bu çeşitliliklerden biridir. Ancak, GTIBR'ye (2015) göre şirketler bu çeşitliliği pek kullanmamaktadır. Ayrıca, kadınların yöneticilik için gerekli niteliklere sahip olmasına rağmen bu pozisyonlarda yer almaması, çalışma motivasyonunu ve işe olan bağlılı̆̆ düşürerek kadın çalışanların verimliliğini azaltmaktadır. $\mathrm{Bu}$ durumdan, hem çalışanlar hem de şirketler zarar görmektedir (Morrison vd., 1987).

Son yıllarda yapılan araştırmalar, tüm dünyada kadınların, sayıları az da olsa, cam tavanı kırmaya başlayarak liderlik pozisyonlarına yükseldiklerini göstermektedir (Catalyst, 2016; Eagly \& Carli, 2007). Uluslararası düzeyde yapılan analizlere göre iş dünyasının üçte birinde hiçbir kadın yönetici bulunmazken, tüm dünyada üst düzey yönetim pozisyonlarının \% 22'sini kadınlar oluşturmaktadır (GTIBR, 2015). Her ne kadar \% 22 yüksek bir oran olmasa da, cam tavanı kırmayı başaran kadınların olduğuna işaret etmektedir. Cam tavanın kırılması elbette önemlidir, ancak kadınların hangi durumlarda yönetici seçildikleri, seçildikleri pozisyonlarda ne derece başarılı olabildikleri, diğer bir ifadeyle cam tavanın kırılmasından sonraki süreçle ilgili olarak da sorulması gereken pek çok soru vardır. Bu bağlamda takip eden kısımda, cam tavanın aşılmasıyla birlikte kadın yöneticilerin karşılaştığı yeni bir sorun olan cam uçurum kavramından bahsedilecektir (Ryan vd., 2016).

\subsection{Cam Uçurum}

1980'li y1llardan beri tartışılan cam tavan kavramı, günümüzde daha çok kişi tarafindan bilinmektedir ve bu farkındalıkla birlikte, kadınların liderlik pozisyonlarına getirilmelerinin önündeki engellerin aşılması için daha çok çaba gösterilmektedir. Ancak, Ryan ve Haslam (2005, 2007), günümüzde kırılmaya çalışılan cam tavanın yerini, örtük ayrımcılığın farklı bir formu olan cam uçuruma bıraktığını göstermiştir. Araştırmacılar (Bruckmüller, Ryan, Rink \& Haslam, 2014; Haslam \& Ryan, 2008; Ryan \& Haslam, 2005, 2007) kadınlar ve erkeklerin ulaşmış oldukları liderlik pozisyonlarının farklı olabileceğini düşünerek bir dizi çalışma yürütmüştür. Araştırmacılara göre, kadınlar, cam tavanı kırıp liderlik pozisyonlarına ulaştıklarında, "cam uçurum" adını verdikleri ayrımcılığın farklı bir gizil formuyla karşılaşmakta ve erkeklere göre daha fazla bedel ödemektedir (Ryan \& Haslam, 2007; Ryan vd., 2016). "Cam 
uçurum" kadınların erkeklere göre, başarısızlık ihtimalinin yüksek olduğu daha riskli durumlarda lider olarak atanmasını ifade etmektedir. Buna göre; erkek yönetici adayları, ekonomik olarak yükselişte olan şirketlerde yönetici olarak tercih edilirken, kadın yönetici adayları ekonomik durumu çöküşte olan şirketlerde yönetici olarak seçilmektedir (Bruckmüller vd., 2014; Haslam \& Ryan, 2008). Başka bir deyişle; cam uçurum, kurum koşulları normal seyrettiğinde veya kurum yükselişte olduğunda erkeklerin, kurumun performansında düşüş ve başarısızlık ihtimali olması durumunda ise kadınların yöneticilik pozisyonu için daha uygun değerlendirilmesi anlamına gelmektedir (Haslam \& Ryan, 2008).

Cam uçurum araştırmalarının temelini Judge'ın (2003) The Times dergisinde yazmış olduğu makale oluşturmuştur. Judge (2003) makalesinde, FTSE 100 şirketleri olarak adlandırılan, Londra borsasının piyasa değeri en büyük şirketlerini, 2003 yılı verilerine göre, incelemiştir. Judge'ın istatistiksel verilere dayanarak ulaştı̆̆ sonuçlara göre FTSE 100 şirketlerinde, yüksek yönetici pozisyonlarında kadın çalışan sayısının daha çok olduğu şirketler, FTSE 100'deki diğer şirketlere göre daha kötü performans sergilemektedir ve tamamen erkekler tarafindan yönetilen şirketler, FTSE 100 ortalamasının üzerinde bir performansa sahiptir. Judge (2003), bu bulgular 1şı̆̆ında, kadın yöneticilerin iş dünyasında performansı olumsuz etkilediği çıkarımını yapmış ve kadın yöneticiler olmadan şirketlerin daha iyi performans sergileyebileceği görüşünü savunmuştur. Kadın yöneticilerin varlığı ve şirketlerin kötü performansı arasında nedensellik kuran bu yaklaşım, kadınlara yönelik ayrımcılığın ve olumsuz kalıp yargıların sürdürülmesinde ve desteklenmesinde güçlü bir kanıt niteliği taşımaktadır.

Judge'ın (2003) bu dikkat çekici bulgularını değerlendiren Ryan ve Haslam (2005), aynı veri setini kullanarak daha kapsamlı ve çok yönlü bir araştırma yürütmüştür. Araştırmacılar, mevcut yöneticilerin işe başladıkları zamanı ve şirket performanslarındaki dalgalanmalar gibi çeşitli durumsal faktörleri de analize dahil ederek, şirketlerin kadın ve erkek yöneticilerin işe alınmadan önceki ve sonraki performansını incelemiştir. Sonuç olarak, Ryan ve Haslam (2005) Judge'ın (2003) yaptığı değerlendirmeyi sorgulatan farklı sonuçlara ulaşmıştır. Bulgular, ekonomik olarak performansın düşüşte olduğu şirketlerde yönetici pozisyonları için kadınların tercih edildiğini, ekonomik olarak performansın daha durağan ve yükselişte olduğu şirketlerde yönetici pozisyonları için erkeklerin tercih edildiğini göstermiştir. Ayrıca, elde edilen yeni bulgulara göre; kadın yöneticilerin yoğunlukta olduğu şirketlerin, erkekler tarafindan yönetilen şirketlere göre performansı daha fazla artmış; ancak başlangıçtaki eşitsizlik nedeniyle erkek yöneticiler daha başarılı olarak algılanmıştır. $\mathrm{Bu}$ bulgular, kadın yöneticilerin şirketlerin kötü performans sergilemesine neden olmadığını, aksine şirketlerin düşüş yaşadığ 1 durumlarda liderlik avantajına sahip olduğunu göstermiştir. Ryan ve Haslam (2005) bu çalışmalarında yöneticilerin performansını değerlendirirken, mevcut ekonomik performansın yanı sıra yöneticilerin pozisyona geldikleri koşulların da göz önünde bulundurulması gerektiğine dikkat çekmiştir. Araştırmacılar kadınların cam tavanı kırdıktan sonra riskli yöneticilik pozisyonlarına getirilmelerini, ayrımcılığın örtük bir formu olarak değerlendirmiş ve bu durumu "cam uçurum" olarak adlandırmıştır.

Kadınların erkeklere göre başarısızlık ihtimalinin yüksek olduğu daha riskli yöneticilik pozisyonlarına atanması, Türkiye'de yürütülen çalışmalar da dahil olmak üzere birçok araştırma tarafından doğrulanmıştır (Brady, Isaacs, Reeves, Burroway \& Reynolds, 2011; Cook \& Glass, 2014; Haslam \& Ryan, 2008; Uyar, 2011). Cam uçurumun karar verme testleriyle değerlendirildiği araştırmalarda, katılımcılara genellikle hangi yönetici adayının hangi şirket için uygun olacağı ve adayın liderlik nitelikleri açısından yeterli olup olmadığı açık olarak sorulmaz. Bunun yerine, daha dolaylı yollarla ölçümler yapılır (detaylı yöntem bilgisi için bkz. Haslam \& Ryan, 2008). Bu araştırmalarda, eğitim ve tecrübe gibi özellikler açısından birbirinin tamamen aynısı olan iki kısa özgeçmiş oluşturulur. Özgeçmişlerden birine kadın adayın ismi yazılırken diğerine ise erkek adayın ismi yazılır. $\mathrm{Bu}$ iki özgeçmişin yanı sıra, biri finansal açıdan sağlam, yükselişte olan ve başarılı bir çizgide ilerleyen; diğeri finansal açıdan riskli, düşüşte olan ve başarılı bir performans gösterme ihtimali düşük olan iki ayrı şirket performansı hikayesi oluşturulur. $\mathrm{Bu}$ şirketlerin de geleneksel cinsiyet rollerine göre sadece kadın (örn., kozmetik sektörü) veya erkeğe (örn., otomotiv sektörü) hitap etmeyecek, her iki cinsiyet için de uygun olabilecek (örn., bankacılık sektörü) şekilde seçimine dikkat edilir. Katılımcıların bir kısmına yükselişte olan şirket performansı hikayesi, bir kısmına da düşüşte olan şirket performansı hikayesi verilir ve adayların bu şirketler için uygun bir yönetici olup olmadığ ve/veya yetkin bir lider olarak algilanıp algılanmadığına dair sorular sorulur. $\mathrm{Bu}$ araştırmalar, katılımcıların, erkek adayları finansal açıdan yükselişte olan şirketler için daha uygun bir yönetici adayı olarak gördüğünü, kadın adayları ise finansal açıdan düşüşte olan şirketlerde yönetici olarak daha uygun değerlendirdiklerini göstermiştir (örn., Haslam \& Ryan, 2008). Ashby, Ryan ve Haslam'ın (2007) hukuk öğrencileriyle yaptığ 
çalışmada ise, katılımcılardan iki önemli dava için uygun adayları seçmeleri istenmiştir. Bir dava oldukça olumsuz bir üne sahip olan ve kamuoyundan çok eleştiri alan bir dava olarak sunulurken, diğer dava iyi gitmekte olan ve sorunsuz bir dava olarak tarif edilmiştir. Sonuçlar yine cam uçurum kavramıyla tutarlıdır: Kadın avukatlar problemli dava için, erkek avukatlar ise iyi giden dava için daha uygun adaylar olarak değerlendirilmiştir. Çoğu çalışma, cam uçurum etkisi için cinsiyet farklılığına işaret etmemektedir ancak cam uçurum etkisinin özellikle erkek katılımcılarda belirgin olduğunu gösteren araştırmalar da mevcuttur (Ryan, Haslam, Hersby \& Bongiorno, 2011).

Kadınların riskli durumlarda tercih edilmesi, sadece şirket yönetimlerinde değil, politik seçim ve adaylık süreçlerinde de gözlemlenmektedir. Örneğin, Birleşik Krallık seçimlerinde kadınların, kazanılması daha zorlu olacak bölgelerde aday olarak gösterildiği, erkeklerin ise kazanılma ihtimali kuvvetli olan bölgelerde aday olarak gösterildiği bulunmuştur (Ryan, Haslam \& Kulich, 2010). Deneysel ve arşivsel birçok araştırma da, kadın yönetici istihdamının kurumsal (Haslam \& Ryan, 2008) ve politik (Ryan vd., 2010) başarısızlıkların nedeni değil, sonucu olduğunu ortaya koymuştur. Araştırmacılar (örn., Haslam \& Ryan, 2008; Ryan \& Haslam, 2005; Ryan, Haslam, Hersby, Kulich \& Atkins, 2007; Ryan vd., 2010) cam uçurumun farklı alanlarda var olduğunu öne sürmekle birlikte, cinsiyet ayrımcılığının ve cinsiyetçiliğin kurumsallaştırılmış olduğu geleneksel cinsiyet rollerine dayalı iş bölümünü benimseyen kültürlerde ve erkek egemen iş alanlarında özellikle belirgin olabileceğini belirtmişlerdir (Ryan \& Haslam, 2007).

\section{KADINLAR NEDEN CAM TAVAN VE CAM UÇURUMLA KARŞI KARŞIYA KALIR?}

Harvard Üniversitesi rektörü Larry Summers kadınların işleri için fedakarlık yapmak istemediğinden ve işlerine yüksek düzeyde bağlılık göstermeye hazır olmadığından, bilinçli olarak liderlik pozisyonlarında olmayı tercih etmediğini iddia etmiştir (Ryan vd., 2007a). Bu iddiayla tutarlı olarak, kadınların yöneticilik pozisyonundayken işlerini bıraktığını gösteren istatistikler de mevcuttur. Örneğin, Ryan ve Haslam'ın (2007) paylaştığı bir araştırma bulgusu, erkek CEO'ların işte kalma süresinin (8.2 yıl), kadın CEO'ların (4.8 y1l) neredeyse iki katı olduğunu göstermiştir. Ancak, kadınların liderlik pozisyonlarından ayrılmaları, onların istekli olarak işlerinden ayrıldıklarına yeterli kanıt oluşturmamaktadır.
Tersine, başka bir araştırma bulgusu, ișten ayrılan kadınların \%90'ının iş hayatından tamamen uzaklaşmadığını ve \%70'inin ya kendi şirketini kurduğunu ya da tam zamanlı farklı bir işte çalışmaya devam ettiğini göstermiştir (Townsend, 1996). Bu bulgu, Larry Summers'ın iddia ettiği gibi kadınların işle ilgili heves ve bağlılıklarının olmamasının değil, farklı etkenlerin kadınların işten ayrılmasına neden olduğuna işaret etmiştir. Belki de kadın ve erkeklerin iş yerinde farklılaşan deneyimleri ya da kadınların işteki terfilerde erkeklerle eşit şanslara sahip olmadıklarına veya olamayacaklarına dair inançları işlerinden doyum almamalarına, işten ayrılmalarına neden olmaktadır. $\mathrm{Bu}$ da sonuç olarak, kurumların yönetici pozisyonları için çok uygun olan parlak kadın çalışanları kaybetmelerine sebep olmaktadır.

Araştırmacılar, kadınların yüksek pozisyonlarda karşılaştıkları önyargılara ilişkin farklı kuramsal açıklamalar getirmeye çalışmıştır. Takip eden kısımda, araştırmacıların odaklandıkları faktörler başlıklar altında ele alınacak, gelecekte yürütülecek çalışmalar için önerilerde bulunulacaktır.

\subsection{Erkek-Yönetici ve Kadın-Kriz Eşleşmesi}

Rol Uyumu Kuramı'na göre, kadın liderlere yönelik önyargının nedeni kadınlara ilişkin kalıp yargılarla başarılı liderlere yapılan atıfların uyumsuz olmasıdır (Eagly, Makhijani \& Klonsky, 1992). Yapılan araştırmalarda, başarılı orta düzey yöneticilerin, kadınların ve erkeklerin nasıl algılandığını anlamak için katılımcılardan 92 farklı özelliğin (örn., neşeli, itaatkar, yaratıcı, nazik) kadın, erkek ve yöneticiler için ne kadar tanımlayıcı olduğunu değerlendirmeleri istenmiştir. Gerek Almanya, İngiltere (Schein \& Mueller, 1992) gibi bireyci kültürlerde, gerekse Çin ve Japonya gibi toplulukçu kültürlerde (Schein, Mueller \& Lituchy, 1996) yürütülen çalışmalar hem kadınların hem de erkeklerin, erkekleri ve yöneticileri özellikleri açısından daha benzer algıladığını göstermiştir. Her ne kadar hem kadın hem erkek katılımcılar yönetici ve erkek özelliklerini daha benzer algılasa da, kadın ve yönetici özelliklerinin benzerliğinde cinsiyet farkı bulunmuştur. Bu ülkelerdeki kadın katılımcılar erkeklerle kıyaslandığında, kadın ve yönetici özelliklerini daha benzer algılamışlardır. Sümer'in (2006) Rol Uyumu Kuramı çerçevesinde Türkiye'de yürüttüğü bir çalışmada da benzer bulgular elde edilmiştir. Çalışma bulguları, yöneticilerin değerlendirildiği 92 özelliğin, görev yönelimi, ilişki yönelimi ve duygusal denge olmak üzere üç farklı boyuta ayrılabileceğine işaret etmiştir. Yapılan analizler, yöneticilerin hem kadın hem erkek katılımcılar tarafından bu üç boyutta da yüksek değerlendirdiğini göstermiştir. Aynı çalışmada, katılımcılar bu özellikleri, kadınlar ve 
erkeklerin sahip olduğu özellikler açısından da değerlendirmiştir: Kadınlar ilişki yöneliminde yüksek, görev yönelimi ve duygusal denge boyutlarında düşük değerlendirilirken; erkeklere görev yönelimi ve duygusal denge boyutlarında yüksek skorlar verilmiştir. Sonuçlar, kadınların ve yöneticilerin bir boyutta (ilişki yönelimi boyutunda) benzer algılandığını ancak erkeklerin ve yöneticilerin iki boyutta (duygusal denge ve görev yönelimi boyutları) benzer algılandığını ortaya koymuştur. Rol Uyumu Kuramı doğrultusunda yürütülen bu çalışmalar, kadınlara kıyasla yöneticilerin ve erkeklerin özelliklerinin birbiriyle daha uyumlu algılandığını göstermiş, yönetici dendiğinde zihinde erkek bir figürün canlandığına işaret etmiştir.

Rol Uyumu Kuramı, kadınların yüksek pozisyonlara getirilmemesini ifade eden cam tavan kavramını anlamak için uygun bir kuramdır. Ancak bu kuram, başarılı kurumlarda erkeklerin, düşük performans gösteren kurumlarda ise kadınların tercih edilmesini ifade eden cam uçurum kavramını anlamak için yeterli değildir. Bu bağlamda, Ryan ve arkadaşları (2011), her koşulda tercih edilen bir liderlik tipindense, farklı koşullarda farklı liderlik özelliklerinin daha etkili olabileceği görüşünü savunarak, kadınların özelliklerinin krizle baş etme durumunda daha istenir olabileceğini ifade etmiştir. Araştırmacıların, kriz ve kadın eşleşmesini anlamaya yönelik yürüttükleri araştırmanın sonuçları, krizle baş etme durumunda erkek ve başarılı şirket yöneticilerinin özellikleri (örn., kararlı, agresif) ile kadın ve başarısız şirket yöneticilerinin özelliklerinin (örn., sempatik, pasif) birbiriyle daha benzer tanımlandığını göstermiştir. İkinci çalışmada, araştırmacılar katılımcılardan başarılı ve başarısız şirketler için ideal yönetici özelliklerini değerlendirmelerini istemiştir. Sonuçlar, başarılı şirketlerin ideal yöneticileri için daha çok erkekler için tanımlayıcı olan özelliklerin (örn, kararlı, iddialı, baskın); başarısız şirketlerin ideal yöneticileri içinse daha çok kadınlar için tanımlayıcı olan özelliklerin (örn., sempatik, sezgisel, taktiksel, yardımsever, anlayışl, başkalarının duygularına karşı hassas, yaratıcı) istenir olduğunu göstermiştir. Brückmüller ve Branscombe'un (2010) yürüttükleri çalışma da şirketin başarılı olduğu durumda erkeklerle, kriz durumunda kadınlarla ilişkilendirilen özelliklerin lider seçiminde etkili olduğuna işaret etmiştir. Ayrıca bu çalışma, şirketin durumunun erkek ve kadın adaylarla ilgili izlenimler üzerinde de etkili olduğunu göstermiştir. Şirketin başarılı olduğu durumda kadın ve erkek adaya yönelik yapılan değerlendirmelerde, her iki aday kişilerarası ilişkilerde eşit derecede başarılı olarak değerlendirilirken, şirketin başarısız olduğu durumda kadın aday, erkek adaya göre, kişilerarası ilişkilerde daha başarılı algılanmıştır. Araştırmacılar, sonuçların kadın-kriz eşleşmesi ile ilişkilendirilebileceğini söylemişlerdir.

Elde edilen bulgular, kadınların daha çok kriz durumuyla eşleştirilmesinin ve kadınlara ait olduğu düşünülen özelliklerin kriz durumunda daha istenir olmasının, cam uçurumun altında yatan mekanizma olabileceğine işaret etmektedir. Ancak, kadın-kriz eşleşmesinin cam uçurumun temel kaynaklarından biri olmayacağına dair işaretler de alan yazında mevcuttur. Örneğin, yapılan analizler 2001, 2005 ve 2010 İngiltere genel seçimlerinde etnik azınlık grup üyelerinin beyazlara kıyasla daha başarısız olduğunu ama bunun azınlık grup üyelerinin karşıt adayın daha güçlü olduğu durumlarda aday gösterilmiş olmasıyla ilişkili olduğunu göstermiştir (Kulich, Ryan \& Haslam, 2014). Bu bulgu, sadece kadınların değil diğer azınlık grup üyelerinin de daha riskli pozisyonlara seçildiklerine kanıt sunarak, kadın-kriz eşlemesinin cam uçurumu açıklamada yetersiz kalabileceğine işaret etmiştir. Ayrıca, yapılan farklı bir çalışma, şirketin başarısız olduğu fakat liderden beklenenin aktif rol oynama, şirketin durumunu iyileştirme ve şirket adına sözcülük yapma olduğu durumlarda erkeklerin; şirketin başarısız olduğu ancak liderden beklenenin pasif rol oynama ve başarısızlığın sorumluluğunu alma olduğu durumlarda kadınların lider olarak tercih edildiklerini göstermiştir. Diğer bir ifadeyle, aktif liderlik gereken durumlarda erkekler seçilirken; başarısızlığın sorumluluğunu üstlenerek, günah keçisi pozisyonunda kalacakları liderlik rolleri için kadınlar uygun görülmüştür (Ryan vd., 2011). Bu bulgular ise, cam uçurumun altında yatan nedenin sadece kadın-kriz özelliklerindeki uyum olmayacağını düşündürmektedir.

Üzerinde durulması gereken bir diğer önemli nokta ise, cam uçurum ve kadın-kriz/erkek-yönetici eşleşmesine dair çalışmaların genellikle birbirinden bağımsız olması ve bu nedenle yapılan çıkarımların dolaylı olmasıdır. Diğer bir ifadeyle, kadınkriz/erkek-yönetici eşleşmesi yapanların yapmayanlara göre cam uçurumu temsil eden tercihler yapıp yapmadıklarına dair çok fazla kanıt yoktur. İleride yürütülecek çalışmalarda, katılımcıların örtük ve açık düzeyde hem kadınkriz/erkek-yönetici eşleşmesine dair değerlendirmeleri hem de cam uçurumu yansitan yönetici tercihleri aynı çalışma içinde ele alınarak, kadınlarla krizi ve erkeklerle yöneticiliği daha kuvvetli şekilde eşleştirenlerin cam uçurumu yansitan tercihler yapıp yapmadikları değerlendirilmelidir. 


\subsection{Başarısızlık Durumunda Statükonun / Normun Devam Ettirilmemesi}

Cam uçurum kavramına ilișkin bir diğer olası açıklama ise başarısızlık durumunda var olan normun devam ettirilmesindense, şirketin değişikliğe gitme ihtiyacı hissetmesidir. Diğer bir ifadeyle, şirketi başarısızlığa götüren normu, yani erkek liderle olan yönetimi devam ettirmek yerine değişim ve dönüşümü sağlayabilecek farklı bir sisteme, yani kadın liderin yönetimde olduğu sisteme geçmek şirket açısından daha tercih edilebilir bir seçenek olabilir.

Cam uçurumla ilişkili olabilecek bu açıklama, şirketin geçmişteki liderleriyle ilgili bilgilerin manipüle edildiği bir çalışma ile doğrudan test edilmiştir (Brückmüller \& Branscombe, 2010). Bu çalışmada, öncelikle katılımcılara şirketin geçmişteki yöneticileri ile ilgili bilgi verilmiştir. Katılımcıların yarısına geçmişteki üç liderin kadın olduğu bilgisi verilirken, kalan yarısına geçmişteki liderlerin erkek olduğu bilgisi verilmiştir. Devamında ise katılımcılara şirketin durumunu belirten (başarılı ya da kriz durumuna) bir yazı sunulmuştur ve sonrasında katılımcılar şirket için uygun lideri seçmişlerdir. Sonuçlar, cam uçurum etkisiyle paralel olarak, geçmiş yöneticilerin erkek olduğu koşulda, şirket başarılıysa erkek liderin, şirket krizdeyse kadın liderlerin daha yüksek oranda seçildiğini göstermiştir. İlginç olan, cam uçurum etkisinin geçmişte kadın lidere sahip şirketlerde görülmemesidir. Kadın ve erkek liderlerin tercih oranı, geçmişte kadın lidere sahip şirketler için farklılaşmamış, kadın ve erkekler aynı oranda tercih edilmiştir. Elde edilen bulguların, şirketlerdeki kadın lider sayısının artırılmasının cam uçurum etkisinin yok edilmesi için önemli bir faktör olabileceğine işaret ettiğini söylemek de mümkündür.

$\mathrm{Bu}$ noktada, cevaplanması gereken soru, şirket başarılıysa statükoyu devam ettirme ve şirket krizdeyse değişim yaratma eğiliminin şirketin geçmişteki liderleri kadınsa neden görülmediğidir. Brown, Diekman ve Schneider'in (2011) yaptığı çalışma bu soru için yanıt oluşturabilecek niteliktedir. Araştırmacılar, hem açık hem de örtük düzeyde erkek liderlerin statükoyla, kadın liderlerinse değişim ile ilişkilendirildiğini göstermişlerdir. Kuşkusuz başarı durumunda başarının devam ettirilmesi, kriz durumundaysa yapılacak değişikliklerle şirketin durumunun iyileştirilmesi daha kritiktir. Ancak, geçmişteki liderleri kadın olan şirketlerde, başarı ve kriz durumunda, kadın ve erkek adayların aynı oranda tercih edilmesi, kriz durumunda, kadın liderlerin aktif lider rolünden çok, pasif kalarak başarısızlığın sorumluluğunu üstlenmesine dair beklenti (Ryan vd., 2011), kriz durumunda kadın liderin değişiklik yaratarak şirketin başarısını sağlayacağına dair açıklamanın sorgulanması gerektiğine de işaret etmektedir.

\subsection{Kadınlara ve Erkeklere Yönelik Örtük Tutumlar}

Cam uçurumun sadece kadınlar için değil diğer azınlık grup üyeleri için de bir tehdit olması ve kadınların şirketin başarısızlığı için "günah keçisi" ilan edilebilecekleri pozisyonlar için lider seçilmeleri (Ryan vd., 2011) cam uçurumun altında yatan nedenin kadınlara ve kadın liderlere yönelik örtük düzeydeki olumsuz tutumlar olabileceğini düşündürmektedir.

Önyargı konusunun oldukça hassas bir konu olması ve sosyal istenirlik gibi nedenlerle kişilerin önyargılı tutumlarını rapor etmeyi tercih etmemesi, önyargı alan yazınındaki güncel çalışmalarda örtük tutumların daha fazla yer almasına neden olmuştur. Örtük tutumlar, katılımcıların farkındalığının ve kontrolünün dişında olan tutumları ölçen örtük ölçüm yöntemleriyle değerlendirilmektedir. Örtük ölçüm yöntemlerinde katılımcılara fikir ve duyguları açıkça ve doğrudan sorulmaz. Bir uyarana verilen tepkinin süresinden ya da verilen tepkinin doğruluğundan kişinin tutumuyla ilgili çıkarımlarda bulunulur (Greenwald vd., 2009). Örneğin, bilgisayardaki bir testte katılımcilardan önce kadınları insani bilimlerle ve erkekleri fen bilimleriyle olabildiğince hızlı ve az hata yaparak eşleştirilmesi istenmiştir. Testin sonraki aşamasında ise kadınları fen bilimleri ve erkekleri insani bilimlerle eşleştirmeleri istenmiştir. Sonuçlar, kadınların insani bilimlerle ve erkeklerin fen bilimleriyle eşleştirildiği aşamada katılımcıların çok daha hızlı tepki verdiklerini göstermiştir (Nosek, Banaji \& Greenwald, 2002). Bu çalışma bilinçli olarak farkında olmasak bile, örtük düzeyde zihnimizde kadınları insani bilimlerle erkekleri ise fen bilimleriyle eşleştiriyor olabileceğimizi göstermektedir.

Alan yazındaki bulgular, kişilerin söylemine dayanan açık tutumların sözel ve düşünce süzgecinden geçen davranışları yordamada daha kuvvetli olduğunu, fakat sözel olmayan ve dolaylı olarak değerlendirilen davranışların örtük tutumlar tarafından daha güçlü şekilde yordandığını göstermiştir (Dovidio, Kawakami, Johnson, Johnson \& Howard, 1997). Bu doğrultuda, kadın ve erkek liderlerle ilgili olarak zihindeki otomatik düşüncelerin / çağrışımların cam uçurumu yansıtan kararlar alınmasıyla ilişkili olabileceği düşünülebilir. Brown, Diekman ve Schneider (2011) örtük düzeyde erkek liderlerin statükoyla kadın liderlerinse değişim ile ilişkilendirildiğini 
göstermiştir, ancak örtük düzeyde kadın ve erkek liderlere yönelik olumlu / olumsuz tutumların cam uçurumla ilişkisine odaklanan ileride yürütülecek çalışmalar konu hakkında daha fazla bilgi sahibi olmamızı sağlayacaktır. Ayrıca örtük ölçüm yöntemleri kullanılarak test edilmesi gereken önemli bir araştırma sorusu da, başarı ve krizle ilgili eşik altı / subliminal ifadelere maruz kaldıktan sonra kişilerin, kadın ve erkekleri yönetici olarak ne derece tercih edecekleridir.

\subsection{Korumacı ve Düşmanca Cinsiyetçilik}

Cam uçurum kavramının altında yatan motivasyonları açiklayabilecek kuramlardan biri de Çelişik Duygulu Cinsiyetçilik Kuramıdır (Glick \& Fiske, 1996). Erkeklerin kadınlardan üstün olduğunu savunan cinsiyetçilik kavramını Glick ve Fiske (1996) iki ayrı boyuta ayırarak kavramsallaştırmıştır. Araştırmacılara göre, cinsiyetçilik kadınlara yönelik önyargılı, ayrımcı ve düşmanca davranışları içerdiği gibi kadınların zayıf, korunmaya muhtaç varlıklar olduğuna dair inançları da içerebilir. Geleneksel cinsiyetçilik anlayışını yansıtan Düşmanca Cinsiyetçilik (DC) kadınlara yönelik öfkeyi, cezalandırmayı ve erkeklerin üstün olduğu algısını içermektedir. Cinsiyetçiliğin diğer boyutu olan korumacı cinsiyetçilikse (KC), kadınların, yüceltilmesi ve korunması gerektiği algısını içerir. Dışarıdan bakıldığında KC, cinsiyetçilikmiş gibi algılanmasa da cinsiyet eşitsizliğini sürdürür ve meşrulaştırır. Cinsiyetçiliğin iki farklı türü olan $\mathrm{KC}$ ve DC'nin, şirket yönetiminde kadın adayın uygunluğunun değerlendirilmesinde ve kadınların hirslı ve tehditkâr olarak algılanmasında etkili olabileceği düşünülmektedir.

Alan yazındaki birçok araştırmada, KC ve DC'nin kadın yöneticilere yönelik tutumlar üzerindeki etkisi araştırılmıştır. Genel olarak bu araştırmaların bulguları $\mathrm{KC}$ ve DC'nin kadınlarla ilgili değerlendirmelerde farklı kavramlarla ilişkili olduğunu ortaya koymuştur. Örneğin, Glick, Diebold, Balley-Werner ve Zhu (1997) DC'nin, geleneksel rollerden uzak, kariyer odaklı kadınların olumsuz değerlendirilmesiyle ilişkili olduğunu, KC'nin ise kariyer odaklı kadınların değerlendirilmesiyle ilişkisiz olduğunu, aksine geleneksel rollere sahip olan ev kadınlarının olumlu değerlendirilmesiyle ilişkili olduğunu ortaya koymuştur (Glick vd., 1997). Ancak, farklı çalışmalarda KC'nin geleneksel cinsiyet rollerini ihlal eden kadınlara yönelik olumsuz tutumlarla da ilişkili olduğu ortaya koyulmuştur (örn., Viki, Massey \& Masser, 2005).

Sakall1-Uğurlu ve Beydoğan'ın (2002) KC ve DC'nin kadın yöneticilere yönelik tutumlarla ilişkisini inceledikleri araştırma da diğer araştırma bulgularıyla tutarlıdır. Bu korelasyonel araştırmada, $\mathrm{KC}$ ve kadın yöneticilere yönelik tutumlar arasında ilişki bulunmazken, DC skoru yüksek olan katılımcılar -özellikle erkek katılımcılar- kadın yöneticileri olumsuz olarak değerlendirmiştir. Kadın-erkek cinsiyet rollerinin çok belirgin olduğu ataerkil bir ülke olan Türkiye'de (Sakall1-Uğurlu \& Beydoğan, 2002) kadınların iş hayatında yer almaları ve özellikle erkek işi olarak algılanan yöneticilik konumunda çalışmaları, erkeklerin kadınları ve tüm kaynakları kontrol etme ve yönetme hakkına sahip olduğu ve kadınlardan daha fazlasını hak ettiği algısıyla (Eagly \& Mladinic, 1994) uyuşmadığından olumsuz değerlendirilmektedir.

Cam tavan ve cinsiyetçilik araştırmaları, DC'nin kadınların yönetimde rol almasına ilişkin olumsuz değerlendirmelerle ve ayrımcılıkla ilişkili olabileceğine işaret etmektedir. Örneğin, Masser ve Abrams (2004) araştırmalarında kadın ve erkek yönetici adaylarının pozisyona uygunluğuna dair değerlendirmede $\mathrm{KC}$ ve DC'nin etkilerini incelemiştir. Araştırma bulguları, KC'nin erkek egemenliği olan bir kurumda yönetici olarak işe alınacak adayların işe uygunluğunun değerlendirilmesinde bir etkisinin olmadığını göstermiştir. DC'nin ise kadın adayın olumsuz değerlendirilmesiyle ve erkek adayın pozisyon için daha uygun olarak değerlendirilmesiyle ilişkili olduğu ortaya koyulmuştur.

Erkek egemenliğini, geleneksel cinsiyet rollerini ve kadının ekonomik bağımlılı̆̆ını meşrulaştıran DC'nin (Glick \& Fiske, 1997) kariyer yönelimli kadınlara yönelik olumsuz tutumlarla ilişkili olması olağandır. Kadın adayların değerlendirilmesinde, kadınların bireysel özellikleri ve davranışlarının yanı sıra, erkeklerin statüsüne yönelik tehdit oluşturup oluşturmadıkları da belirleyici olabilir (Masser \& Abrams, 2004). KC ve adayların değerlendirilmesi arasında ilişskinin olmayışı, KC puanları yüksek olan kişilerin, kadınların geleneksel cinsiyet rollerini ihlal etmeyeceği ve dolayisıyla erkekler için tehdit oluşturmayacağına ilişkin algisından kaynaklanabilir (Masser \& Abrams, 2004).

İlgili yazında, kadın yöneticilere yönelik olumsuz tutumların özellikle DC ile ilişkili olduğu, KC'ninse çoğunlukla etkisiz olduğu görülmektedir. Ancak, cam uçurum kavramı kadınların riskli durumlarda lider olarak atanmasını içerdiğinden, sadece kadın yöneticilere yönelik tutumların incelenmesi cam uçurumu açıklamak için yeterli olmayacaktır. Alan yazında, çelişik duygulu cinsiyetçilik ve cam uçurum araştırmaları sınırlı sayıdadır. Ryan ve Haslam (2007) kadınların liderliğin riskli olduğu 
koşullarda yönetici olarak atanmasının düşmanca cinsiyetçi kadın ve erkeklerin geleneksel cinsiyet normlarına uymayan kadınları cezalandırma ve başarısız olduklarını görme isteğinden kaynaklandığı öne sürmüştür. Buna karşın Haslam ve Ryan'ın (2008) cinsiyetçiliği tek boyutlu bir kavram olarak ele aldığı deneysel araştırmalarında cinsiyetçilik ve kadınların riskli durumlarda lider olarak atanması arasında ilişki bulunamamıştır. $\mathrm{Bu}$ bulgular 1şığında, Ryan ve Haslam (2007), KC'nin cam uçurumu anlamada yardımcı olabileceğini öne sürmüştür. Kadınların problemli liderliğe atanmasında, onlara bir iyilik yapıyormuş gibi hissetmenin ve aynı zamanda kadınları destekliyormuş gibi görünüp onları gelişim ve yükselme firsatlarından uzak pozisyonlara atayarak ayrımcılık iddialarının önüne geçmeyi istemenin etkili olabileceği düşünülmektedir. Ancak, Haslam ve Ryan'ın (2008) araştırmasında KC ve DC ölçekleri kullanılmadığından, çelişik duygulu cinsiyetçilik ve cam uçurum arasındaki ilişkiye dair net bir çıkarım yapılamamaktadır.

Cam uçurum ve çelişik duygulu cinsiyetçilik arasındaki ilişki Türkiye'de benzer zamanlarda yürütülen iki ayrı tez çalışmasıyla araştırılmıştır (Ak-Kurt, 2011; Uyar, 2011). Ak-Kurt'un (2011), araştırmasında cam uçurumun varlığ edilememiş ve cam uçurumun cinsiyetçilikle ilişkisi de gözlenmemiştir. Buna karşın, Uyar'ın (2011) bulguları cam uçurumun varlığını destekler niteliktedir. Uyar (2011) ayrıca kadın ve erkek adayların şirket için uygunluğunun ve liderlik yeteneklerinin algilanması üzerinde DC ve KC'nin aracı değişken olarak rol oynayıp oynamadığını test etmiş ve KC'nin anlamlı rol oynadığını göstermiştir. Bulgulara göre, şirket performansının kötüye gittiği senaryoda, KC puanının düşük olması, kadın adayın daha uygun ve daha yetkin olarak algılanmasıyla ilişkilidir.

Yukarıda bahsi geçen cinsiyetçilik ve kadın yöneticilere karşı tutumlar arasındaki ilişkiyi inceleyen araştırma bulguları, bu ilişkinin daha fazla incelenmesi gerektiğini ortaya koymaktadır. Alan yazında cam uçurum ve cinsiyetçilik arasındaki ilişkiyi inceleyen araştırmaların sınırlı oluşu, Türkiye'de yürütülen iki araştırma arasında farklı bulguların elde edilmesi bu ilişkinin yeniden test edilmesinin gerekliliğine işaret etmektedir.

\subsection{Sosyal Kimlik}

Cam uçurumu yansıtan tercihlerin kadınlara yönelik önyargının bir yansıması olabileceği söylenmektedir (Ryan \& Haslam, 2007). Önyargıyla ilgili alan yazındaki çalışmalara baktığımızda ise, özellikle etnik kimlikle ilişkili olarak yürütülen çalışmalarda, sosyal kimlikle özdeşleşmenin önyargının öncülü olarak ele alındığ 1 pek çok çalışmaya rastlamak mümkündür. Buna paralel olarak, Sosyal Kimlik Kuramı da, kişilerin kendi iç-grubunu kayıran değerlendirmeler yaptığ argümanını ortaya atmış (Tajfel, 1982) ve bu önerme pek çok görgül çalışma ile desteklenmiştir.

Cam uçurumu yansıtan kararlarda cinsiyet farkına işaret eden, kadınlardansa erkeklerin kadınları riskli pozisyonlar için uygun gördüğünü gösteren (örn., Hunt-Earle, 2012) çalışmalar mevcuttur ancak cam uçurumun öncülü olarak doğrudan sosyal kimlikle özdeşleşmeyi ele alan araştırmalar yoktur. Sosyal Kimlik Kuramı çerçevesinde, erkek kimliğiyle daha çok özdeşleşenlerin, kadınları, başarılı şirketlerin liderlik pozisyonlarına daha az ve kriz durumundaki şirketlerin liderlik pozisyonlarına daha yüksek oranda getirebilecekleri düşünülebilir.

Cinsiyet kimliği ile özdeşleşmenin cam uçurumu yansitan tercihleri ne derece yordadığı doğrudan araştırılmasa da, cinsiyetin ve cinsiyet kimliği ile özdeşleşmenin cam uçuruma yönelik tutumlar ve cam uçurumun nedenlerine yönelik açıklamalar üzerindeki etkisi araştırılmıştır. Ryan, Haslam ve Postmes'in (2007) yürüttüğü çalışmada, erkeklerin \%50'sinden fazlası cam uçurum etkisinin varlığını sorgularken bu oran kadınlarda sadece $\% 5$ olmuştur. Ayrıca bu çalışmada, erkeklerin kadınların cam uçurum pozisyonlarına getirilmelerini, kadınların bu pozisyon için daha uygun oldukları, şirketin stratejik karar verme gerekliliği gibi görece daha hafif sebeplere bağladıkları; kadınların ise erkeklerin kendi gruplarını kayırmaları, kadınlar için alternatif fırsatların olmayışı, cinsiyetçilik gibi daha ağır sebeplerle ilişkilendirdiği görülmüştür. Kadın ve erkekler arasında bahsedilen farklılıklar özellikle cinsiyet kimliği ile daha yüksek oranda özdeşleşenlerde daha fazladır. Bahsedilen bulgular sosyal kimlikle özdeşleşmenin cam uçurumla da ilişkili olabileceğine ve sosyal kimlikle özdeşleşmenin cam uçurumla ilişkisine doğrudan odaklanan çalışmalara ihtiyaç duyulduğuna işaret etmektedir.

\subsection{Kriz Durumunda Altın Firsatı Yakalayan(!) Kadın Liderler}

Haslam ve Ryan (2008) kriz durumunda kadın liderin seçilmesini, başarısızlık durumundaki liderlik pozisyonunun, erkekten çok kadın lider için bir firsat olarak görülmesiyle ilişkilendirilebileceğine işaret etmiştir. Ashby ve arkadaşlarının (2007) yaptığı çalışmanın sonuçları, cam uçurumun kaynağına yönelik getirilen bu açıklamayla tutarlıdır. Hukuk öğrencileriyle yürütülen çalışma, erkek avukat için, zorlu bir davayı almanın riskli ve düşük düzeyde firsat 
sağlayan bir durum olarak algılandığını ancak kadın avukat için bu davayı almanın daha az riskli ve daha yüksek düzeyde firsat sağlayan bir durum olarak görüldüğünü göstermiştir. Kısacas1, kriz durumundaki liderlik kadın için bir firsat olarak algılanırken, erkek için risk taşıyan bir durum olarak görülmektedir. Ancak, kadın için altın fırsat olduğu düşünülen bu pozisyonlar, kadını başarısızlığın sorumluluğunu üstlendiği ya da üstlenmek zorunda kaldı ğ 1 bir pozisyona, diğer bir ifadeyle "günah keçisi" pozisyonuna düşürebilmektedir. Ayrıca, yöneticilik pozisyonlarına getirilmiş kadınlarla yapılan mülakatlar, kadınların bu pozisyonlardaki görevlerinde sosyal destek alamadıklarına, şirketteki görevlerini başarılı bir şekilde yerine getirmeleri için gerekli olan bilgilendirme/iletişim ağlarına dahil edilmediklerine işaret etmiştir (Ryan vd., 2007b; Wilson-Kovacs, Ryan \& Haslam, 2006). Bu gibi deneyimler, kadınların getirildikleri pozisyonlarda başarısız olmaları ve şirketin başarısızlığından sorumlu tutulmamalarındaki süreç için tetikleyici faktörlerdir.

Kriz durumundaki şirketler kamuoyunun dikkatini daha fazla çekmektedir ve genellikle şirketin başarısızlığı durumsal/çevresel faktörlere değil liderle ilişkili bireysel nedenlere atfedilmektedir (Wright, 2014). Ayrıca, kadın liderin başta olması ve kriz gibi iki ender görülen olayın rastlantısal olarak benzer zamanlarda meydana gelmesi, gözlemcilerin bu iki olayı ilişkilendirmesi için kolaylaştırıcı etken olabilmektedir (Ryan vd., 2016). Bu durum ise, başarısızlık durumunda çevresel faktörlerin değil, kadın liderin başarısılığgn kaynağı olarak görülebileceğine işaret etmektedir (Ryan vd., 2011).

Kuşkusuz cam uçurum kavramını anlamaya yönelik farklı bakış açıları bu kavramın altında yatan mekanizmayı anlayabilmemiz açısından önemlidir ancak elde edilen farklı araştırma bulguları, getirilen açıklamaları sorgulamamız gerektiğini ve konuyla ilgili daha kapsamlı çalışmaların yapılması gerektiğini de göstermektedir.

\subsection{Cam Uçurum Etkisinin Sonuçları}

Cam uçurum kavramının ortaya çıkması ve üzerinde çalışılmaya başlanması oldukça yenidir. Ancak, bu çalışmada şimdiye kadar üzerinde durulan araştırmalardan da anlaşılacağı gibi, cam uçurumun kaynağına yönelik farklı çalışmaların yürütüldügünü söylemek mümkündür. Cam uçurumun hem çalışanlar hem de kurum açısından sonuçları ise daha az üzerinde durulan bir konu olmuştur. Ryan ve arkadaşlarına (2007a) göre kadınlar açısından dengeli olmayan ev ve iş hayatındaki görevler ve kadınların sosyal anlamda ve iş konusunda yeterince destek alamamasının bir sonucu olarak, kadınlar yüksek pozisyonlara geldikçe, erkeklere kıyasla, daha fazla stres yaşamaktadırlar. Yaşadıkları yüksek stres nedeniyle de, cam uçurumla karşı karşıya kalan kadınlar için kurum ve işle kimliklenmede ve iş doyumunda azalma gibi olumsuz sonuçlar ortaya çıkabilmektedir.

Kadınların getirildikleri cam uçurum pozisyonlarının, kadınların kariyerleri açısından da, oldukça olumsuz etkilere sahip olabileceği açıktır. Krizdeki şirketlerde lider değişiklikleri daha çok olmaktadır ve iyi performans göstermeyen şirketlerden ayrılan yöneticilerin daha sonraki işlerinde lider pozisyonuna getirilme olasılıkları daha düşüktür (Ferris, Jagannathan \& Pritchard, 2003). Bu da kriz durumunda, yani başarısızlık ihtimalinin yüksek olduğu koşullarda, daha yüksek oranda başa getirilen kadınların karşılaştı̆̆ 1 bir başka risktir: Kriz durumda, yani başarısızlık ihtimalinin yüksek olduğu koşulda, yönetici seçilen kadınların hem halihazırda çalıştıkları hem de dolaylı olarak gelecekte çalışabilecekleri yöneticilik pozisyonları tehlike altındadır.

Şimdiye kadar üzerinde durulmayan bir diğer önemli nokta ise, cam uçurumun şirketler açısından sonuçlarıdır. Kriz ve başarı durumunda erkek liderleri göreve getiren şirketlere kıyasla, kadın liderleri göreve getiren şirketlerin başarı durumları, kriz ve başarı durumunda göreve getirilen kadın ve erkek liderlerin motivasyonları, iş tatminleri, kurumla kimliklenme düzeyleri de incelenmeye değer bir konular arasındadır.

\section{TARTIŞMA}

Geçmiş yıllara kıyasla kadın işverenleri tercih etmede bir artış gözlense de, Amerika'da yaklaşık 2000 kişiden toplanan veri, cinsiyet fark1 olmaksızın, kadınlardan çok erkek işverenlerin tercih edildiği yönünde bir sonucu ortaya koymuştur (Newport \& Wilke, 2013). Benzer şekilde, Eagly ve arkadaşlarının (1992), 61 araştırmaya dayanan meta-analiz çalışması, kadın liderlerin erkek liderlere göre daha olumsuz değerlendirildiğini ve kadınlara yönelik bu olumsuz değerlendirmenin özellikle otokratik ve yönlendirici tarzda liderlik ve erkeklerin daha baskın olduğu iş alanları söz konusu olduğunda daha da arttığını göstermiştir. Araştırmacılar, kadın yöneticilere yönelik rapor edilen önyargının varlığına işaret eden bu araştırma sonuçlarını, kadınların geleneksel olarak erkeklerin hakim olduğu iş alanlarına girdiklerinde 'bunun bedelini' olumsuz tepki ve değerlendirmelerle ödedikleri şeklinde 
yorumlamıştır. Diğer bir ifadeyle, kadınlar yönetici olmayı başarsalar bile, olumsuz deneyimler yaşamaya devam etmektedir. Kuramsal ve görgül çalışmalar kadınların işle ilgili deneyimlerinin erkeklerin deneyimlerinden çok daha farklı olduğunu ortaya koymaktadır. $\mathrm{Bu}$ çalışmada da, yönetici pozisyonundaki kadınların gözle görülür olumsuz deneyimlerine ek olarak, onları olumsuz etkileyen ve önyargının gizil formları olarak tanımlanabilecek, cam tavan ve cam uçurum kavramlarından bahsedilmiştir. Kadınların yüksek pozisyonlara getirilmesinin önündeki engelleri ifade eden cam tavan ve kadınların daha çok riskli yöneticilik pozisyonlarına getirilmesini ifade eden cam uçurum kavramları, önyargının hukuken kabul görmese de, varlığını değişik formlarda devam ettirdiğini göstermektedir. Cam uçurumun öncülü olarak etkili olabilecek faktörler alan yazında incelenmektedir. Ancak, bulgulardaki tutarsızlıklar ve konuyla ilgili henüz incelenmemiş faktörler nedeniyle ek çalışmalara ihtiyaç duyulmaktadır. Cam uçurum kavramını uluslararası ya da kültürler arası karşılaştırmalar yaparak ele alan araştırmalar alan yazında yer almamaktadır. Bireyci ve toplulukçu kültürlerde, cinsiyet eşitsizliğinin az ve çok olduğu ülkeler düzeyince yapılacak karşılaştırmalı çalışmalara ihtiyaç duyulmaktadır.

Cam uçurumun öncüllerinin keşfedilmesinin yanı sıra, kadınların iş yerinde karşılaştığı açık ve örtük düzeydeki önyargıları yok etmeye yönelik müdahale yöntemlerinin geliştirilmesi de bir o kadar önem taşımaktadır. TUİK'in (2015) verileri, kadınların eğitim düzeyindeki artışın kadınların işgücüne katılımıyla olumlu ilişkisi olduğunu; yükseköğretim mezunu kadınların işgücüne katılım oranının \%71,3 iken bu oranın, okur-yazar olmayan kadınlarda \%16, lise altı eğitimli kadınlarda \%25,8 ve lise mezunu kadınlarda \%31,9 olduğunu göstermiştir. Diğer bir ifadeyle, eğitimli kadınlar iş hayatında daha çok var olabilmektedir. Bunun yanı sıra, yürütülen bilimsel çalışmalar, cinsiyete yönelik farkındalığ 1 artıracak ders ve programların kadınlara yönelik önyargıyı azalttığını, cinsiyet eşitliği sağlayacak politikalara daha olumlu bakılmasını ve erkeklerin kendi ayrıcalıklı konumlarını daha çok fark etmelerini sağladığını ortaya koymuştur (örn., Case, 2007; Pettijohn \& Walzer, 2008). Bu bağlamda, kadınların eğitim almasını sağlamanın ve kadınlara yönelik önyargılarla ilgili farkındalığı artıracak programların yoğun şekilde uygulanmasının önyargı ve ayrımcılığa karşı atılabilecek önemli adımlar olduğu söylenebilir.

$\mathrm{Bu}$ yazıda ele alınan araştırmalar, genel olarak önyargının ve özel olarak da bu yazıda ele alınan cam uçurum kavramının altında yatan temel faktörlerin ortaya çıkarılmasına ve önyargıların kişiler ve kurumlar açısından sonuçlarına yönelik daha çok çalışmaya ihtiyaç duyulduğunu göstermektedir. Ayrıca cam duvar, cam tavan ya da cam uçurum gibi ayrımcılık formlarıyla sadece kadınlar değil, etnik ya da dini kimliği, cinsel yönelimi ya da sosyo-ekonomik düzeyi nedeniyle dezavantajlı olan grup üyeleri de karşılaşmaktadır. Dolayısıyla, bu gruplarla ileride yürütülecek çalışmalar, ayrımcılığın farklı formlarının farklı gruplardaki yansımaları konusunda bize daha geniş bir çerçeveden bakma imkanı verecektir. 


\section{KAYNAKÇA}

Ak-Kurt, D. (2011). Glass cliff in relation to hostile and benevolent sexism (Yayınlanmamış yüksek lisans tezi). Orta Doğu Teknik Üniversitesi, Ankara.

Ashby, J., Ryan, M.K. \& Haslam, S.A. (2007). Legal work and the glass cliff: Evidence that women are preferentially selected to lead problematic cases. Journal of Women and the Law, 13, 775-794.

Brady D., Isaacs K., Reeves M., Burroway R. \& Reynolds M. (2011). Sector, size, stability, and scandal: Explaining the presence of female executives in Fortune 500 firms. Gender in Management: An International Journal, 26, 84-105.

Brown R. (2010). Prejudice: Its social psychology (2. Bask1). Chichester: Wiley-Blackwell.

Brown, E.R., Diekman, A.B. \& Schneider, M.C. (2011). A change will do us good: Threats diminish typical preferences for male leaders. Personality and Social Psychology Bulletin, 37(7), 930-941.

Bruckmüller, S. \& Branscombe, N.R. (2010). The glass cliff: When and why women are selected as leaders in crisis contexts. British Journal of Social Psychology, 49, 433-451.

Bruckmüller S., Ryan M.K., Rink F. \& Haslam S.A. (2014). Beyond the glass ceiling: The glass cliff and its lessons for organizational policy. Social Issues and Policy Review, 8, 202-232.

Case, K.A. (2007). Raising male privilege awareness and reducing sexism: An evaluation of diversity courses. Psychology of Women Quarterly, 31(4), 426-435.

Catalyst (2016, Eylül 19). Women in $S \& P 500$ companies. http://www.catalyst.org/publication/132/us-womenin-business

Cook, A. \& Glass, C. (2014). Women and top leadership positions: Towards an institutional analysis. Gender, Work, and Organization, 21, 91-103.

Davidson, T. (2003). Prejudice. New York: Franklin Watts.

Dovidio, J.F., Kawakami, K. \& Gaertner, S.L. (2002). Implicit and explicit prejudice and interracial interaction. Journal of Personality and Social Psychology, 82(1), 62-68.

Dovidio, J F., Kawakami, K., Johnson, C., Johnson, B. \& Howard, A. (1997). On the nature of prejudice: Automatic and controlled processes. Journal of Experimental Social Psychology, 33(5), 510-540.

Eagly, A.H. \& Carli, L.L. (2007). Through the labyrinth: The truth about how women become leaders. Boston: Harvard Business Press.
Eagly, A.H., Makhijani, M.G. \& Klonsky, B.G. (1992). Gender and the evaluation of leaders: A metaanalysis. Psychological Bulletin, 111, 3-22.

Eagly, A.H. \& Mladinic, A. (1994). Are people prejudiced against women? Some answers from research on attitudes, gender stereotypes, and judgments of competence. European Review of Social Psychology, 5(1), 1-35.

Ferris, S.P., Jagannathan, M. \& Pritchard, A.C. (2003). Too busy to mind the business? Monitoring by directors with multiple board appointments. The Journal of Finance, 58(3), 1087-1111.

Glick, P., Diebold, J., Bailey-Werner, B. \& Zhu, L. (1997). The two faces of Adam: Ambivalent sexism and polarized attitudes toward women. Personality and Social Psychology Bulletin, 12, 1323-1334.

Glick, P. \& Fiske, S.T. (1996). The Ambivalent Sexism Inventory: Differentiating hostile and benevolent sexism. Journal of Personality and Social Psychology, 70, 491-512.

Glick, P. \& Fiske, S.T. (1997). Hostile and benevolent sexism: Measuring ambivalent sexist attitudes toward women. Psychology of Women Quarterly, 21, 119135

Grant Thornton International Business Report (2015). Women in business: The path to leadership. https://www.grantthornton.global/globalassets/1.member-firms/global/insights/ibrcharts/ibr2015_wib_report final.pdf

Greenwald, A.G., Poehlman, T A., Uhlmann, E. \& Banaji, M.R. (2009). Understanding and using the Implicit Association Test: III. Meta-analysis of predictive validity. Journal of Personality and Social Psychology, 97(1), 17-41.

Haslam, S.A. \& Ryan, M.K. (2008). The road to the glass cliff: Differences in the perceived suitability of men and women for leadership positions in succeeding and failing organizations. The Leadership Quarterly, 19, 530-546.

Hegewisch, A. \& Hartmann, H. (2014). Occupational segregation and the gender wage gap: A job half done. Washington, DC: Institute for Women's Policy Research.

Hunt-Earle, K. (2012). Falling over a glass cliff: A study of the recruitment of women to leadership roles in troubled enterprises. Global Business and Organizational Excellence, 31(5), 44-53.

Hymowitz, C. \& Schellhardt, T.D. (1986, 24 Mart). The glass ceiling: Why women can't seem to break the invisible barrier that blocks them from the top jobs. The Wall Street Journal, s.1. 
Judge, E. (2003). Women on board: Help or hindrance? The Times, s. 21.

Kulich, C., Ryan, M.K. \& Haslam, S.A. (2014). The political glass cliff: Understanding how seat selection contributes to the underperformance of ethnic minority candidates. Political Research Quarterly, 67(1), 84-95.

Masser, B. \& Abrams, D. (2004). Reinforcing the glass ceiling: The consequences of hostile sexism for female managerial candidates. Sex Roles, 51, 609615.

Morrison, A.M., White, R.P. \& Van Velsor, E. (1987). Breaking the glass ceiling: Can women reach the top of America's largest corporations? Reading, MA: Addison-Wesley.

Newport, F. \& Wilke, J. (2013). Americans still prefer a male boss. http://www.gallup.com/poll/165791/americansprefer-male-boss.aspx

Nosek, B.A., Banaji, M.R. \& Greenwald, A.G. (2002). Math $=$ male, $m e=$ female, therefore math $\neq$ me. Journal of Personality and Social Psychology, 83(1), 44.

Örücü, E., Kılıç, R. \& Kılıç, T. (2007) Cam tavan sendromu ve kadınların üst düzey yönetici pozisyonuna yükselmelerindeki engeller: Balıkesir ili örneği. Celal Bayar Üniversitesi İ̈F Yönetim ve Ekonomi Dergisi, 14(2),117-135.

Pettijohn, T.F. \& Walzer, A.S. (2008). Reducing racism, sexism, and homophobia in college students by completing a psychology of prejudice course. College Student Journal, 42(2), 459-468.

Ragins, B.R., Townsend, B. \& Mattis, M. (1998). Gender gap in the executive suite: CEOs and female executives report on breaking the glass ceiling. Academy of Management Executive, 12, 28-42.

Rowe, M.P. (1990). Barriers to equality: The power of subtle discrimination to maintain unequal opportunity. Employee Responsibilities and Rights Journal, 3(2), 153-163.

Ryan, M.K. \& Haslam, S.A. (2005). The glass cliff: Evidence that women are over-represented in precarious leadership positions. British Journal of Management, 16, 81-90.

Ryan, M.K. \& Haslam, S.A. (2007). The glass cliff: Exploring the dynamics surrounding the appointment of women to precarious leadership positions. Academy and Management Review, 32(2), 549-572.

Ryan, M.K., Haslam, S.A., Hersby, M.D. \& Bongiorno R. (2011). Think crisis-think female: The glass cliff and contextual variation in the think manager-think male stereotype. Journal of Applied Psychology, 96(3), 470-484.

Ryan, M.K., Haslam, S.A., Hersby, M.D., Kulich, C. \& Atkins, C. (2007a). Opting out or Pushed off the Edge? The glass cliff and the precariousness of women's leadership positions. Social and Personality Psychology Compass, 1(1), 266-279.

Ryan, M.K., Haslam, S.A. \& Kulich, C. (2010). Politics and the glass cliff: Evidence that women are preferentially selected to contest hard-to-win seats. Psychology of Women Quarterly, 34, 56-64.

Ryan, M.K., Haslam, S.A., Morgenroth, T., Rink, F., Stoker, J. \& Peters, K. (2016). Getting on top of the glass cliff: Reviewing a decade of evidence, explanations, and impact. The Leadership Quarterly, 27(3), 446-455.

Ryan, M.K., Haslam, S.A. \& Postmes, T. (2007b). Reactions to the glass cliff: Gender differences in the explanations for the precariousness of women's leadership positions. Journal of Organizational Change Management, 20(2), 182-197.

Sabharwal, M. (2015). From glass ceiling to glass cliff: Women in senior executive service. Journal of Public Administration Research and Theory, 25, 399-426.

Sakall1-Uğurlu, N. \& Beydoğan, B. (2002). Turkish college students' attitudes toward women managers: The effect of patriarchy, sexism, and gender differences. Journal of Psychology, 136, 1-11.

Schein, V.E. \& Mueller, R. (1992). Sex role stereotyping and requisite management characteristics: A cross cultural look. Journal of Organizational Behavior, 13, 439-447

Schein, V.E., Mueller, R., Lituchy, T. \& Liu, J. (1996). Think manager-think male: A global phenomenon? Journal of Organizational Behavior, 17, 33-41.

Sümer, H.C. (2006). Women in management: Still waiting to be full members of the club. Sex Roles, 55, 63-72.

Tajfel, H. (1982). Social psychology of intergroup relations. Annual Review of Psychology, 33, 1-39.

The Economist (2015). The Glass-ceiling index.. http://www.economist.com/blogs/graphicdetail/2015/ 03/daily-chart- 1 ? $\mathrm{fsrc}=\mathrm{scn} / \mathrm{tw} / \mathrm{te} / \mathrm{bl} / \mathrm{ed} /$ theglassindex

Townsend, B. (1996). Room at the top for women. American Demographics, 18, 28-37.

Türkiye Büyük Millet Meclisi (2016). Türkiye Büyük Millet Meclisi milletvekilleri dağılımı. https://www.tbmm.gov.tr/develop/owa/milletvekilleri miz_sd.dagilim. 
Türkiye İstatistik Kurumu (2015). Istatistiklerle kadın, 2014.

http://www.tuik.gov.tr/PreHaberBultenleri.do?id=186 19

Uyar, E. (2011). The glass cliff: Differences in perceived suitability and leadership ability of men and women for leadership positions in high and poor performing companies. (Yayınlanmamış yüksek lisans tezi) Orta Doğu Teknik Üniversitesi, Ankara.

Viki, G.T., Massey, K. \& Masser, B. (2005). When chivalry backfires: Benevolent sexism and attitudes toward Myra Hindley. Legal and Criminological Psychology, 10, 109-120.

Wilson-Kovacs, D.M., Ryan, M. \& Haslam, A. (2006). The glass-cliff: women's career paths in the UK private IT sector. Equal Opportunities International, 25(8), 674-687.

Wright, K. (2014). Think crisis-think female? An evaluation of psvchological and structural processes behind the glass cliff effect. 영미연구, 31, 433-452. 